\title{
O mestre subterrâneo: as afinidades eletivas entre Marcus Garvey e Kwame Nkrumah
}

The underground master: The elective affinities between Marcus Garvey and Kwame Nkrumah

\section{Felipe Paiva}

\section{RESUMO}

A característica mais marcante do político e ideólogo ganês Kwame Nkrumah (1909-1972) é seu panafricanismo radical. O significante África tinha para ele o sentido de pátria-mãe, nação a ser construída e reconquistada. Este ímpeto pan-africano foi fruto de um amadurecimento visível em sua trajetória. Nela, o pensador jamaicano Marcus Garvey (1887-1940) desempenhou papel fundamental. Por meio de uma crítica da principal obra de Nkrumah relativa ao panafricanismo, Africa Must Unite! (1963), abordamos neste artigo a relação intelectual entre ambos, procurando demonstrar tanto seus pontos de contato quanto aqueles divergentes.

\section{PALAVRAS-CHAVE}

África; História Intelectual; Recepção

\section{ABSTRACT}

The most remarkable feature of the Ghanian politic and ideologue Kwame Nkrumah (1909-1972) is his radical pan-africanism. The term Africa had for him the meaning of motherland, nation to be built and regained. This panafrican impetus was the result of a visible maturation in his path, in wich the jamaican thinker Marcus Garvey (18871940) performed a fundamental part. Through the critic of the main piece of woek from Nkrumah concerning the pan-africanism, Africa Must Unite! (1963), we cover in this article the intelectual relation between both, seeking to demonstrate the points in wich they converge such as the striking ones.

\section{KEYWORDS}

Africa; Intellectual History; Reception 
O corolário natural da influência é a angústia. Há páginas que não podem ser visitadas impunemente, pois, como disse Tólstoi, elas cavam "sulcos profundos e sensíveis" na mente do leitor (TÓLSTOI 2004, p. 154). Caso estanquem em cicatriz ou se permanecem para sempre abertos, esses sulcos servem para caracterizar o sintoma da influência: a angústia de saber-se devedor de alguém, de um autor predecessor (BLOOM 1973, p. 13).

Assim, caso se aventure mais tarde pela arte da escrita, o outrora leitor terá sempre diante de si um modelo a ser imitado, combatido ou superado. Ao escrever, ele se debate com "pressões estimulantes, deformadoras e reativas das obras de predecessores". Esses antecessores formam um grupo de parceiros dialéticos com os quais pode dialogar ou esgrimir. É a companhia deles que confere "até ao mais complexamente solitário e inovador dos atos criativos a experiência de uma trama compartilhada e coletiva" (STEINER 2003, p. 94-95).

No que diz respeito ao pan-africanismo, ninguém parece ter sido mais inovador que Kwame Nkrumah. Sua ideia de África foi apresentada por ele como a conclusão lógica de uma caminhada longa e, em muitos momentos, solitária. No correr dos seus passos, Marcus Garvey foi um companheiro de viagem importante. Cabe reconstruir a trajetória de Nkrumah em sua procura de uma ideia pan-africana, bem como as relações antitéticas que manteve com seu mestre-companheiro de viagem, Marcus Garvey. Entre ambos havia uma ambiguidade no interior da concórdia, resultado do embate inevitável que surge de todo aprendizado, "conforme seu exercício se modula nos polos da rivalidade e da superação" (STEINER 2003, p. 95-103).

Com efeito, como deverá ficar demonstrado, a relação entre Nkrumah e Garvey obedece àquilo que Harold Bloom chamou por Apofrades, isto é, o retorno dos mortos. O autor-mestre (Garvey), após uma tentativa de ruptura por parte do autordiscípulo (Nkrumah), retorna com força para a obra desse último (BLOOM 1973, p. 23-24). 


\section{Lenhadores e aguadeiros}

Líder da revolução independentista que assumiu o poder em Gana em 1957, Kwame Nkrumah (1909-1972) foi não só um chefe de Estado, mas também um ideólogo de primeira grandeza, pois sua produção é até hoje referência basilar do panafricanismo. Essa estatura intelectual contrasta com o tamanho da aldeia em que nasceu, o povoado de Nkroful. O lugar, seco em oportunidades, o obrigou a viajar constantemente. Primeiro para o vilarejo de Half Assini, afim de adquirir a formação elementar na escola missionária; depois para o então recémfundado colégio de Achimota, então instituição de referência em Gana (NKRUMAH 1962, p. 38).

Formado em Achimota em 1930, passa a pelejar em busca de uma bolsa de estudos em alguma universidade norte-americana, ao mesmo tempo em que trava conhecimento com proeminentes líderes políticos da África Ocidental, tais como o serra-leonês Wallace-Johnson e o nigeriano Nnamdi Azikiwe, que então se encontravam exilados em Gana, além de Kwegyr Aggrey, seu professor em Achimota (SHERWOOD 1996, p. 17-18).

Finalmente, em 1935, seus esforços são recompensados e mais uma vez viaja, agora para os Estados Unidos, para iniciar os estudos na Universidade de Lincoln. Inevitavelmente, entra em contato com um contexto intelectual mais amplo, conhecendo a obra de diversos pensadores e militantes africanos e diaspóricos, dentre os quais o jamaicano Marcus Garvey, cuja obra lhe causou profunda impressão. É a partir desse momento que a ideia pan-africana começa a ganhar corpo e sedimentarse em Nkrumah. Cuidadosamente lapidada, essa escultura só encontraria um toque final mais ou menos definido em 1963, quando publica seu manifesto pan-africano: Africa Must Unite! (África deve unir-se!).

Logo na introdução de sua obra mais importante relativa à ideologia pan-africana, Kwame Nkrumah dá ao leitor importante pista a respeito de suas dívidas intelectuais e da tradição 
ideológica à qual pretende se vincular. Escreveu o então Chefe de Estado que "Os milhões de habitantes da África e Ásia se cansaram de ser lenhadores e aguadeiros, e estão se rebelando contra a falsa crença de que a providência criou a uns para ser os servos de outros" (NKRUMAH 2010, p. 13).

A expressão lenhadores e aguadeiros - Hewers of Wood and Drawers of Water, no original (NKRUMAH 1963, p. IX) - possui uma longa história, que entrelaça em um mesmo nó paradoxal a bíblia inglesa, o pensamento conservador britânico (Tory), os grupos subversivos da origem do capitalismo (negros escravizados, indígenas, além do proletariado europeu) e.... o pan-africanismo. Logo, não foi gratuitamente que Nkrumah a utilizou.

Rachar lenha e carregar água são lidas imemoriais, feitas desde que a espécie humana existe, mas, como binômio terminológico de fortes conotações ideológicas, possui uma origem muito precisa.

William Tyndale cunhou o termo "rachadores de lenha e tiradores de água" em sua tradução do Antigo Testamento, em 1530. A expressão se fez presente em dois textos bíblicos distintos. O primeiro deles é Deuteronômio 29, quando Moisés realiza a aliança com Iahweh. Em tal passagem, o profeta recorda a libertação do povo hebreu do Egito, a caminhada pelo deserto e as batalhas de conquista e sentencia que, inclusive, "o estrangeiro que está no teu acampamento, desde o que corta a tua madeira até o que tira água para ti" também deve fazer parte da aliança com o Criador. A segunda passagem é em Josué 9,21 , na qual o povo gabonita é amaldiçoado com a escravidão, devendo ser "rachadores de lenha e tiradores de água para toda comunidade" (LINEBAUGH; REDIKER 2008, p. 52).

A expressão logo caiu em uso no ambiente britânico, florescendo nas mais diversas descrições sociais desde essa época. Uma primeira explicação para o seu sucesso é o jogo entre as palavras: a aliteração que existe na língua original, o inglês - wood e water - e a assonância - hewers e drawers. Outro fator que explica a atração que o binômio 
exerce é que ele sintetiza a maldição do trabalho que recai nos ombros dos desvalidos.

Seja em Moisés ou Josué, os lenhadores e aguadeiros podem ser vistos em seu sentido literal, mas também como uma larga metáfora na qual se incluem todos aqueles que estão fadados a ter expropriada sua força de trabalho, quase sempre em tarefas das mais embrutecedoras, repetitivas e extenuantes possíveis, como rachar lenha e carregar água. A terminologia caía como uma luva para descrever os bárbaros metropolitanos (o proletariado nascente e a plebe), bem como os de além-mar - os da América e África, principalmente.

Assim, saindo do seu contexto bíblico original, a expressão foi usada pelos artesãos londrinos no século XVII para compor palavras de ordem em protestos trabalhistas. Autores como Swift, Wolfe Tone e James Connoly também a utilizaram para retratar a posição subalterna dos irlandeses diante dos senhores britânicos. Bolingbloke, um tory aristocrático, a utilizou com conotações raciais e reacionárias para descrever os judeus, uma raça distinta fadada a rachar lenha e carregar água. Igualmente, em 1692, a terminologia era usada para descrever Dixcove, forte britânico localizado em Gana, tido pela administração inglesa como "bom lugar para milho, com bastante lenha e água" (LINEBAUGH; REDIKER 2008, p. 58).

Já no século XIX, com a consolidação do capitalismo em sua face industrial, a expressão continua em uso em panfletos cartistas. No mesmo período, ela é grafada por Maxwell Philip em seu romance ambientado no caribe britânico para descrever especificamente os africanos que "deram ao mundo a filosofia, a religião e o governo, mas que agora precisam parar de cortar lenha e carregar água". Quase simultaneamente, Osborne Ward se valeu dela para descrever negros escravizados, plebeus e proletários metropolitanos.

Numa linha sucessória confusa e cercada por inflexões, o binômio passa a ser utilizado no século $X X$ pelos negros estadunidenses, a exemplo de W. E. B. Du Bois, que conclamava 
o povo negro a "escapar do desprezo dos brancos por uma nação de meros rachadores de lenha e tiradores de água" (LINEBAUGH; REDIKER 2008, p. 50-51). Enquanto isso, outro líder da diáspora africana, de maior importância para nossos propósitos, se valeria da metáfora laboral bíblica: Marcus Garvey.

Em um discurso pronunciado em Montego Bay, Jamaica, em 1921, Garvey falava a respeito da ideia de que "o homem Negro, [...] só deve ser lenhador, carregador de água, um servo que lança a vista para ver o branco como amo e senhor, e quem nasceu para crer-se inferior às demais raças, nascido para não portar esperanças" (GARVEY 2013, p. 43).

Nkrumah, como ele próprio gostava de lembrar, era um "cristão não vinculado a nenhuma igreja". ${ }^{1}$ Por esse motivo, certamente ele se bateu com a expressão idiomática dos lenhadores e aguadeiros na tradução da Bíblia em inglês, a qual conheceu pela mão do missionário católico que o educou quando criança. Mais tarde, ele a reencontrou em Garvey, que também era cristão, o que certamente ajudou a criar ou reforçar o vínculo entre a fé que professava e um certo ímpeto libertário difuso.

Em um sentido estreito, ao falar que os africanos não mais seriam lenhadores e aguadeiros, o presidente ganês estava dando a conhecer ao seu público leitor ao menos duas de suas principais influências: o cristianismo e Garvey. Por outro lado, em um sentido mais amplo, Nkrumah estava se vinculando, consciente ou inconscientemente, a uma tradição intelectual maior. Ele se colocava, querendo ou não, ao lado do conjunto de autores e/ou militantes que usaram a citação da escritura como combustível para a subversão e como arsenal literário para o protesto social.

Com efeito, ao se valer do binômio dos lenhadores $e$ aguadeiros, ele não estava somente referenciando duas das mais importantes pedras de seu edifício formativo, senão expressando que, como militante, ele se colocava ao lado dos cartistas e artesãos ingleses, de Swift em sua denúncia da condição irlandesa e, claro, de Garvey. Ele se somava às fileiras 
de todos os que utilizaram o termo para denunciar a espoliação, ajudando a compor uma sucessão ideológica descontínua, não linear e, por isso mesmo, contraditória. Dessa trincheira, ele atirava suas palavras contra a igualmente longa tradição conservadora que se valia da terminologia bíblica com fins diametralmente opostos, para legitimar a opressão, a exemplo de Bolingbloke e os demais tories aristocráticos.

\section{Um desconhecido familiar}

A influência de Garvey não se restringe, no entanto, a apenas uma expressão idiomática. Em sua autobiografia, Kwame Nkrumah é bastante claro a respeito do papel que a obra de Marcus Garvey ocupa em seu panteão pessoal. Segundo seu relato, quando foi estudante universitário nos Estados Unidos, leu e/ou conheceu um número expressivo de autores e militantes que Ihe impressionaram: de Herskovits a Cyril James, de Hegel a Marx, de Lênin a Mazzini. Mas foi com a leitura de Philosophy and Opinions of Marcus Garvey, publicado originalmente em 1923, que o jovem militante Kwame mais se entusiasmou, sendo essa brochura peça fundamental no definitivo engajamento de Nkrumah no ideário da libertação e unidade africana. Do mesmo modo, Nkrumah para sempre se ressentiria de nunca ter tido a oportunidade de conhecer o mestre querido: "Desgraçadamente nunca pude conhecer Garvey" (NKRUMAH 1962, p. 64-65).

Se os escritos garveyanos forem postos em contraponto às linhas escritas por seu discípulo ganês, o entusiasmo logo se explica e a dívida intelectual de um para com o outro logo vem à luz. Se faz presente em Garvey um chamado à libertação negra - sujeita a toda sorte de opressão nas Américas, no Caribe e na África - um apelo anticolonial contundente, e, coroando o argumento, a ideia de uma nação africana unida. Esses elementos também estariam disponíveis na prosa nkrumaniana.

Em 1920, Garvey publicava sua Declaração dos Povos Negros, importante documento composto por denúncias a 
respeito das condições às quais os negros nas américas, especialmente nos Estados Unidos, estavam sujeitos. Ao todo, são 12 tópicos de denúncia e 54 reivindicações.

No terceiro tópico de sua Declaração, Garvey escreve a respeito da ação colonial no continente africano, num tom mordaz que não escapou ao jovem Kwame. As nações europeias, disse Garvey, "têm parcelado entre si e tomado posse da quase totalidade do continente da África, e os nativos são obrigados a entregar as suas terras para estrangeiros e, na maioria dos casos, são tratados como escravos". Para ele, a situação colonial era "injusta e imoral, e nenhum nativo deve respeitar qualquer desse tipo de lei ou prática". Em simultâneo, o negro que estava fora do continente, fosse na Europa, nas Américas ou nas "Índias Ocidentais" era visto como "um proscrito e um leproso entre as raças dos homens, não importando qual seja o caráter e as realizações que o homem Negro possa ter" (GARVEY 2013, p. 87-88).

Para pôr termo a essa situação sinistra - "desumana, anticristã e incivilizada", nas palavras de Garvey - são apresentadas as reivindicações. O receituário a ser aplicado tinha por primeiro ponto a afirmação de que "todos os homens são criados iguais e intitulados para os direitos da vida, liberdade e a busca para a felicidade", tal apelo invocava a ajuda do "Todo Poderoso Deus" e declarava "todos os homens, mulheres e crianças do nosso sangue por todo o mundo cidadãos livres e, os afirmamos como cidadãos livres de África, a Terra Mãe de todos os Negros" (GARVEY 2013, p. 89). A passagem final é de suma importância para a análise. Anos depois de tentar romper com Garvey, Nkrumah também caracterizaria a África como "Terra Mãe de todos os Negros".

É necessário descartar de antemão qualquer hipótese de metáfora ou simbolismo nas palavras de Garvey. O sentido de uma África não só negra, mas também nação de toda uma raça é literal em seu argumento.

Em suas próprias palavras: "acreditamos na liberdade de 
África para o povo Negro do mundo, e pelo princípio da Europa para os europeus e da Ásia para os asiáticos; nós ainda exigimos África para os africanos em casa e no exterior". Garvey estava convencido e determinado a "resolver os nossos próprios problemas pelo resgate da nossa Terra Mãe África das mãos de exploradores estrangeiros", e encontrar lá um governo: "uma nação própria, nossa, forte o suficiente para dar proteção aos membros da nossa raça" (GARVEY 2013, p. 91-97). Haveria, segundo ele, um direito "inerente", em sua própria expressão, do negro em relação ao continente africano, devendo ele se apossar dessa terra então usurpada pelo europeu.

O continente e sua soberania eram, portanto, definidos em termos raciais. Se havia uma pátria para o homem branco e outra para o amarelo ou marrom - termos de Garvey para a Europa e a Ásia - também deveria haver uma para o negro, e esse, por sua vez, "como qualquer outra raça, deve ser governado pela ética da civilização". Igualmente, onde quer que estivessem os negros e negras do mundo formariam "uma comunidade entre si" (GARVEY 2013, p. 91).

Garvey nunca pôs os pés na África. Por conseguinte, seu apelo a uma comunidade negra que transcenderia aos territórios tinha, além de um substrato ideológico, uma motivação bastante pragmática subjacente. Caso seu sonho se concretizasse - isto é, se por ventura a "África para os africanos" saísse do papel - o "africano", cidadão do novo país, deveria ser definido de forma a que ele próprio, Garvey, fosse contemplado no conceito, caso contrário se veria alijado da terra que pretendia sua e alienado da cidadania que queria estabelecer. Tal fato não era possível pela pertença territorial; assim, a cor da pele - ou "raça", em seus termos - foi o elemento retórico de coesão coletiva utilizado para constituir um "nós" identificador. Sua África deveria ser grande, unida e liberta, mas, antes de tudo, deveria ser o país dos negros.

Por tudo o que traz em si o pensamento garveyano seria uma pilastra sólida para um jovem militante africano do pósguerra se apoiar. Entretanto, algo que chama a atenção no 
escrito de Nkrumah Africa Must Unite!, publicado originalmente em 1963, é a quase absoluta ausência de Marcus Garvey na construção do argumento. O nome de Garvey é citado apenas uma vez, e mesmo assim somente como baliza histórica em um capítulo que sintetiza a história do pan-africanismo. Garvey não é citado como referência intelectual; sua obra, ao contrário da de Lênin, Abraham Lincoln ou Gunnar Myrdal não aparece como aporte teórico-reflexivo. A diferença é tanto qualitativa quanto quantitativa.

Os nomes de Lênin e Lincoln são grafados três vezes, tanto na condição de exemplos históricos quanto de referências intelectuais; enquanto Myrdal emerge em dois momentos, somente como referência intelectual. Estando atrás desse trio, Marcus Garvey empata ou mesmo fica atrás em número de ocorrências de nomes menores, colaterais ao argumento ou ainda de figuras que aparecem somente como elemento polêmico, tais como, respectivamente: Jack Woddis, Basil Davidson e Leopold Sédar Senghor.

\section{O parricídio}

No único momento em que é citado, Garvey está muito bem acompanhado por Henry Sylvester-Williams e W. E. B. Du Bois. O papel que representa também é relevante, Nkrumah o considera, ao lado dos outros dois, um dos fundadores do pan-africanismo. Em suas próprias palavras: "Uma importante contribuição ao nacionalismo africano e ao pan-africanismo foi o movimento 'Back to Africa' de Marcus Garvey" (NKRUMAH 2010, p. 159-160).

Depois de citar os pais fundadores, Nkrumah vai desenhando a sucessão de eventos que, em sua opinião, foram os mais importantes na história do pan-africanismo. Cita, principalmente, os diversos congressos pan-africanos organizados por Du Bois, até chegar ao maior de todos os eventos: o congresso de Manchester de 1945, no qual ele 
foi o protagonista. Diz Nkrumah que, nesse congresso, ficou resolvido que os métodos empregados para a independência africana e, consequentemente, a unidade continental se baseariam "na tática da não violência e na não cooperação de Gandhi, em outras palavras, a greve, a desobediência civil e o boicote econômico" (NKRUMAH 2010, p. 161).

Dito isso, Nkrumah escreve que "Em lugar de um movimento bastante nebuloso, vagamente intencionado no nacionalismo negro, o movimento pan-africano se convertera em uma expressão do nacionalismo africano". À diferença do que aconteceu nos demais congressos, a maioria dos participantes era formada por "procedentes da África" (NKRUMAH 2010, p. 161).

O tom usado na passagem anterior dá a entender que, com o congresso de 1945, quando os africanos começaram finalmente a protagonizar o pan-africanismo, o movimento tomara uma forma mais precisa. $O$ adjetivo nebuloso para descrever o nacionalismo negro é peça fundamental para compreender o lugar que Garvey (bem como Du Bois) ocupa nesta obra de Nkrumah.

Em termos objetivos, tudo leva a crer que, para Nkrumah, houve uma inflexão profunda em 1945 e teria sido tal inflexão que teria levado o pan-africanismo a se configurar expressão do nacionalismo africano, sendo a obra dos pais fundadores, Garvey incluso, nebulosa. Nessa altura, Nkrumah via a ideologia garveyana como difusa e seus tons argumentativos teoricamente pobres, pois, ao contrário do pós-1945, estaria nela ausente um método a ser empregado na libertação africana e em sua posterior unidade.

Consequentemente, na construção do argumento dessa obra de Kwame Nkrumah, Marcus Garvey é algo acessório, uma peça de antiquário fadada à obsolescência. Em Africa Must Unite!, ao contrário do que acontece em sua autobiografia, publicada em 1957, ano da independência de Gana, Garvey não é tratado como uma referência teórica, mas tão somente como marco histórico. Duas coisas ajudam a explicar essa 
mudança de postura em relação à obra garveyana.

Em primeiro lugar, cabe considerar o papel que o próprio Nkrumah representa nessa obra. Ele já não é mais, como em sua autobiografia, o recém-empossado chefe de Estado que rememora sua formação e quer dar a conhecer ao público sua odisseia de retorno e de reconquista da pátria. Em Africa Must Unite!, ele já é o prestigiado chefe de Estado que anteriormente pretendia ser. Mais do que isso, já estava no panteão intelectual das novas gerações de militantes africanos, afro-americanos (não só estadunidenses) e do terceiro mundo em geral. Diante do novo papel que desempenhava, cabia a ele se colocar não mais como personagem de uma narrativa a ser contada - papel que inevitavelmente assumia em sua autobiografia - mas antes como autor de uma história, pensador original dotado de brilho próprio. Agora era ele o solista e o compositor de sua própria ária na suíte pan-africana.

Essa mudança de posição e de papel fica bastante evidente tanto na conclusão de sua autobiografia, quanto na introdução de Africa Must Unite!, como se o final de uma obra anunciasse o início da seguinte.

Quando encaminha sua autobiografia para a conclusão, Nkrumah narra sua visita oficial à Libéria em 1953, quando desempenhava a função de primeiro-ministro de Gana - um posto que, naquele contexto, não correspondia ao de Chefe de Estado, visto que oficialmente o país ainda estava sob o jugo britânico. Nessa visita, Nkrumah faz um inflamado discurso no qual diz: "África para os africanos! África para os africanos, mas não segundo a filosofia que predicava Marcus Garvey. Não! Estamos criando outra África para os africanos, com uma concepção distinta". Essa nova concepção repousava no desejo de construir "Um Estado livre e independente. Queremos governarmos em nossa própria terra sem interferência estrangeira, e vamos conseguir que assim seja!" (NKRUMAH 1962, p. 214). Se no início da sua autobiografia Garvey é tratado como o autor mais impactante, nas páginas finais ele é alguém a ser superado. 
Da mesma forma, na introdução de Africa must Unite!, Nkrumah escreve: "Em minha autobiografia, e até certo ponto também em outro de meus livros, I Speak of Freedom, tratei de mostrar como e por que se desenvolveu e triunfou a luta pela independência naquilo que então se chamava Costa do Ouro (Gana)". Agora, porém, ele pretende "esboçar brevemente quais são os antecedentes africanos e os efeitos de séculos de colonialismo na vida política, econômica e social da África", além de "explicar minha filosofia política baseada na convicção de que são necessárias a liberdade e a unificação da África e de suas ilhas" (NKRUMAH 2010, p. 15).

Destarte, quando escreveu seu livro a respeito da unidade africana, ele já possuía uma considerável obra anterior. A diferença entre as publicações, como ele mesmo afirma, se refere ao fato de Africa Must Unite! ser tanto um livro que trata da história como, também, ser uma empreitada em "filosofia política". A pretensão que tinha em ser um pensador original aparece com bastante evidência.

Como geralmente acontece com os que se pretendem vanguarda, ele precisava, nesse novo papel que assumia, evidenciar sua singularidade. Era preciso, dentre outras coisas, realizar o parricídio para que seu argumento ganhasse os devidos contornos de ineditismo. $O$ assassinato foi feito de maneira ambivalente, sopesando o respeito pelo pai morto cuja contribuição havia sido "importante" - com suas limitações. Assim, ao fim e ao cabo sua ideia havia sido "nebulosa".

A bem da verdade, em Africa Must Unite! Nkrumah não diz diretamente que a obra garveyana fosse nebulosa, mas que o "nacionalismo negro" era. Por esse motivo, para pleno entendimento da questão, cabe ler essa obra paralelamente à sua autobiografia. Nela, Nkrumah afirma que Garvey "se preocupava com o nacionalismo negro ao contrário do nacionalismo africano" (NKRUMAH 1962, p. 74 - grifos nossos). Sendo assim, por uma dedução lógica, se o "nacionalismo negro" era algo nebuloso, a obra de Garvey também seria, pois era com tal ideologia que o autor jamaicano se alinhava, segundo Nkrumah. 
Evidenciada a tentativa, mas não o sucesso, do parricídio, é preciso analisar as possíveis causas desse evento, o que, exatamente, teria levado Nkrumah a hostilizar o antigo mestre.

\section{As armas do crime}

É justo supor que uma parte dessa ruptura com o nacionalismo negro de Garvey relacione-se com sua dívida para com a academia e, mais precisamente, de seu assumido tributo para com Melville Herskovits (NKRUMAH 1962, p. 19).

Herskovits foi um proeminente antropólogo estadunidense de ascendência judaica. Pela altura em que o jovem Kwame chegou nos Estados Unidos, ele já era respeitado entre seus pares numa posição de prestígio merecidamente mantida até hoje. Herskovits foi particularmente importante no debate intelectual estadunidense por defender - em meio a um contexto no qual o racismo era o item mais vendido pelos mercadores do ódio - a igualdade das raças humanas e o respeito ao qual todas elas têm merecimento, rompendo com a hierarquia racial então hegemônica que colocava o negro na base de uma pirâmide obscena, cujo topo era habitado, naturalmente, pela cultura branca protestante. Do ponto de vista institucional, seu impacto também foi tremendo: estabeleceu e instigou a criação de diversos programas e cursos de cultura e história negra e africana (GERSHENHORN 2004, p. 3-4).

Na parte mais produtiva de sua carreira, cujo ápice se deu com a publicação do livro The Myth of the Negro Past (1941), Herskovits esteve especialmente interessado em demostrar a riqueza e a complexidade da cultura africana e afro-americana. Fugindo do cercado estadunidense, ele foi pesquisar em solo africano e em solo americano, no correto sentido da palavra, tendo visitado o então Daomé, o Haiti, o Suriname e o Brasil (GERSHENHORN 2004, p. 5). Em que pese suas inevitáveis limitações, sua visão algo pluralista das culturas africanas e afro-americanas auxilia a não trancafiar um arco-íris numa jaula monocromática. 
Segundo seu próprio relato, Nkrumah teve conhecimento dessas ideias quando de sua estadia nos Estados Unidos e defendeu as teses de Herskovits no então pulsante debate acadêmico estadunidense (NKRUMAH 1962, p. 64). Logo, ao contrário de Garvey, Nkrumah tinha conhecimento científico o suficiente para não subestimar tanto a diversidade continental. Daí sua recusa em aceitar o "nacionalismo negro" garveyano. Mas as diferenças não se devem unicamente à influência acadêmica, uma vez que pressões do entorno político imediato foram também determinantes.

Em seu manifesto pan-africano, os termos com os quais Nkrumah define a África e, consequentemente a cidadania africana, são condizentes antes ao fator territorial, e menos ao racial. Em muitos momentos de seu livro, Nkrumah rotula como africanos Estados nos quais o negro não compõe o maior contingente populacional, referindo-se, em geral, aos Estados norte-africanos e com maior insistência à República Árabe Unida, como então era chamado o Egito após sua efêmera união com a Síria.

Caso Nkrumah seguisse acriticamente o receituário de Garvey e definisse a África em termos exclusivamente cromático-raciais, colocaria em risco todo e qualquer apoio estratégico e intelectual que poderia receber dos panafricanistas árabes norte-africanos, ${ }^{2}$ e colocaria também em risco a relação amistosa que mantinha com quase todos eles, especialmente com o egípcio Gamal Abdel Nasser, de quem era amigo pessoal. Nkrumah não poderia (e não queria) abrir mão dessas boas relações. Não somente por questões sentimentais pessoais, mas também porque, no momento em que publicava os preceitos de sua ideologia pan-africana, o não alinhamento aparecia como uma alternativa diplomática viável e promissora, cabendo a ele procurar os aliados mais próximos dentro do conjunto de nações que então compreendia o terceiro-mundo. Seus vizinhos do Norte não poderiam ser esquecidos.

Além disso, ao contrário de Garvey, Nkrumah nascera e vivera na África. Tinha dentro de si não só o sentimento de
2 - Muitos políticos e intelectuais árabes africanos defenderam abertamente, ainda que em níveis muito distintos de comprometimento, o pan-africanismo, entendido em termos de união e solidariedade continental. Uma lista concisa dos principais nomes do pan-africanismo norte-africano deve incluir o tunisino Habib Bourguiba (1903-2000), o marroquino Mehdi Ben Barka (1920 - 1965), o egípcio Gamal Abdel Nasser (1918-1970) e o líbio Muamar Kadafi (1942-2011). 
solidariedade racial fruto da opressão indizível à qual as negras e negros do mundo estavam (e estão) sujeitos. Tinha também o sentimento de pertencimento a uma terra distinta, a um chão de traços e contornos próprios. Ao contrário de Garvey, seu pertencimento ao lugar era direto. Sua cidadania africana poderia ser reclamada pelo critério comum do pertencimento territorial, do nascimento no chão natal, não ficando dependente de um vínculo estabelecido a posteriori - a descendência, e, consequentemente, o critério da cor, como no caso de Garvey.

Portanto, em Africa Must Unite!, a forma como definia os significantes "África" e "africano" era dessemelhante de Garvey tanto por uma questão pragmática - estabelecer e reforçar estrategicamente o apoio dos Estados árabes, cujos líderes também falavam em união africana - como também por uma questão sentimental condizente à sua trajetória de vida, em muito diferente daquela de seu professor jamaicano. Entretanto, essa posição não o blindava de contradições ideológicas. A recusa da "raça" como fator de coesão coletiva não foi uma constante absoluta em sua obra, caso seja vista em conjunto.

\section{Hamlet e o espectro do pai}

Em outros momentos de sua trajetória, Nkrumah falou sobre o poder negro e a necessidade de colaboração e união entre os negros africanos e os da diáspora. Nesse caso, o que imprime diferença entre o "poder negro" de Nkrumah e o "nacionalismo negro" de Garvey não é o apelo à população negra e a conclamação a rebelar-se, mas os meandros da argumentação de cada um. Para Nkrumah, a libertação negra deveria estar interligada com o socialismo e com o fim da opressão do homem pelo homem, fosse essa opressão posta em termos raciais ou não. Do mesmo modo, ainda que eventualmente se refira à África como o lar do homem negro, ele não leva adiante o argumento até chegar à mesma conclusão de Garvey: a de que haveria uma nação para cada raça humana. 
Em 1968 - quando já se encontrava destituído da presidência, após o golpe militar ocorrido em Gana em 1966 - Nkrumah publica o panfleto The spectre of Black Power. Nesse manifesto, ele argumenta que a luta dos negros da diáspora e dos africanos é "essencialmente a mesma, uma luta de morte contra a opressão, o racismo e a exploração". O poder negro seria parte "da rebelião mundial do oprimido contra o opressor, do explorado contra o explorador... Este é o elo entre a luta pan-africana para a unidade no continente africano com todos que se esforçam para estabelecer uma sociedade socialista". O poder negro seria, em suma, "o movimento de vanguarda do povo negro, mas abre o caminho para todas as massas oprimidas" (NKRUMAH 1968, p. 10-12). Ao contrário de seu antecessor, Garvey, Nkrumah coloca a questão em termos explicitamente socialistas e marxistas. Não só isso, o poder negro ganha contornos de movimento de vanguarda, em um tom claramente leninista. ${ }^{3}$

Igualmente relevante e reveladora é a dedicatória deste escrito: "Para Ernesto Che Guevara, Ben Barka e Malcolm X". Abaixo da dedicatória, estão os seguintes versos: "Não podemos lamentá-los/Eles não querem nossas lágrimas/ Nós desprezamos a morte/Sabemos que não podemos ser derrotados" (NKRUMAH 1968, p. 10-12). Nkrumah não só coloca a questão racial em termos socialistas marxistas, mas expressa sua dívida com políticos conhecidos por sua filiação a essa tradição de pensamento, reforçando, assim, o vínculo ideológico com essa escola.

É preciso sublinhar que tal dedicatória e os versos que a acompanham, por mais que sirvam como elo e como conclamação à luta, são partes do seu canto do cisne. Um cisne de asas cortadas, como veremos adiante. A dedicatória de Nkrumah é aos tombados, assassinados pelo colonialismo europeu (Ben Barka); pelo imperialismo estadunidense (Che) e pelo racismo deste mesmo país (Malcolm $X$ ). Nkrumah estava cônscio que também para ele a barca de Caronte não tardaria a chegar. Ainda que, ao contrário dos outros três, ele tenha entrado na embarcação por causas naturais.
3 - Nkrumah sempre explicitou sua dívida para com Lênin. Para mais informações a respeito das relações entre Lênin e Nkrumah, ver: (PAIVA 2017, p. 166-178). Disponível em: https://revistas. pucsp. br/index.php/ls/article/view/33251/pdf. 
Desse modo, seu vocabulário, seu tom e suas novas influências apontam para uma ruptura com o ideário de Garvey, que nunca reclamou para si as insígnias do socialismo ou do marxismo. Todavia, essa ruptura está longe de ser absoluta. Se, em 1957, em sua autobiografia, ele diferencia o nacionalismo africano do nacionalismo negro e, em 1963, ele acusa esse último de ser um movimento "nebuloso", em 1968 escreve com todas as letras que a África é "o lar do homem negro e dos descendentes de africanos ao redor do mundo" (NKRUMAH 2010, p. 14). Repetindo, pois, as mesmas palavras outrora pronunciadas por Garvey, que como visto, afirmara ser a África a "Terra Mãe de todos os Negros".

Nkrumah, assim como Garvey, torna a definir o continente africano em termos raciais, ainda que seu léxico esteja preenchido por conceitos inteiramente ausentes do seu mestre jamaicano, como socialismo, vanguarda e exploração do homem pelo homem- e por novos parceiros dialéticos: Che, Barka e Malcolm X. Esse descompasso leva a crer que, para Nkrumah, em sua intimidade, a questão sempre esteve irresoluta, e também que a ruptura com o seu mestre havia sido menos radical do que ele próprio supôs em momentos anteriores de sua obra. Alguns fatores históricos ajudam a explicar essa aparente contradição, bem como o malogro do parricídio intentado por Nkrumah.

A partir de 1957, quando alcança a independência de Gana e publica sua autobiografia, toda esperança estava voltada para dentro da África. A independência de Gana inaugura a chamada década africana, curtíssimo período de tempo em que um futuro emancipado e plenamente independente parecia ao alcance das mãos. Esse sentimento ainda estava na atmosfera em 1963, quando Africa Must Unite! é publicado. O continente parecia ter alçado seu voo rumo à libertação. Mas suas asas eram de cera.

No final da década de 1960, a situação já estava completamente transformada. Especialmente a partir do segundo quartel dos anos de 1960, muitos dos principais líderes independentistas africanos haviam sido assassinados 
(como o queniano Tom Mboya, morto em 1969; o marroquino Medi Ben Barka, desaparecido em 1965 ou o congolês Patrice Lumumba, assassinado ainda em 1961); depostos (como o próprio Nkrumah em 1966; o argelino Ahmed Ben Bella em 1965 e o nigeriano Nnamdi Azikiwe também em 1966); ou se encontravam desnorteados, colecionando derrotas tanto na política interna quanto na externa (a exemplo do egípcio Gamal Abdel Nasser). Em suma, em fins de 1960, Nkrumah estava deposto e amargava um exílio que o condenava a cumprir o papel de leão sem dentes, guardião de lápides.

A queda da revolução africana talvez tenha feito Nkrumah se voltar mais para a diáspora. Ainda que a dimensão diaspórica nunca tenha sido completamente olvidada por Nkrumah - ele sempre a colocou em relevo, fosse em sua obra, fosse em sua prática política, pois inúmeros combatentes dos direitos civis norte-americanos foram entusiasticamente apoiados por ele enquanto foi chefe de Estado. Nomes como Martin Luther King Jr., Malcolm X e Stokely Carmichael estiveram em Gana a convite do então presidente (BIRMINGHAN 1998, p. 95). Além disso, diversos afro-americanos e afro-caribenhos cumpriram funções regulares em seu governo.

Todavia, se anos antes era o continente que parecia ter a vitória ao alcance das mãos, a partir do segundo quartel da década de 1960 era a causa negra estadunidense que ganhava corpo, assumindo um novo léxico e novos métodos, fosse através da luta pelos direitos civis capitaneada por Luther King, ou por organizações mais próximas ao marxismo, tradição à qual Nkrumah se alinhava, como o Partido dos Panteras Negras.

É possível, senão provável, que o malogro da revolução africana e a agudização da luta afro-americana o tenha levado a pôr mais ênfase teórica na causa dos negros e negras algures, contribuindo para uma mudança de contornos na definição da identidade africana. Culminando, ao fim e ao cabo, em um retorno a Garvey. Retorno esse mediado por novos conceitos e novas influências intelectuais. 


\section{Reencontro}

Garvey aparece em Africa Must Unite! como o mestre subterrâneo, o elemento subtextual mais importante a ser considerado. Ao leitor já iniciado na obra nkrumaniana, será bastante evidente a dívida; ao não iniciado, isso talvez escape. Há uma semelhança de ambições em termos gerais - uma África unida, liberta. Aquilo que de Garvey permaneceu em Nkrumah foi a insurgência anticolonial, aquilo que pereceu (ao menos parcialmente) foi a ênfase em um certo racialismo negro na definição do significante África. Ainda que ulteriormente esse mesmo racialismo tenha retornado para sua obra, com novas nuances, é bem verdade.

Em sua caminhada, Nkrumah se esforçou por se desvencilhar do seu mestre subterrâneo. Em alguns momentos apertou o passo e foi, mesmo descalço, abrir sua própria senda. Parecia andar em linha reta para o amanhecer; enquanto na verdade entrava em um desvio fatal, pois, em que pese seu esforço, a trilha se mostrou elíptica. No crepúsculo dos seus dias, reencontrou seu antigo professor. Garvey ainda estava lá. Um sorriso irônico desenhado em sua boca, um olhar compreensivo estampado em sua íris.

Ao discípulo restou voltar a caminhar com o mestre, ainda que ambos estivessem agora muito transformados. Nkrumah trazia consigo tudo o que aprendera em sua caminhada solitária, a memória dos tombados e as novas palavras que bebera das nascentes que encontrou. Garvey, por seu turno, continuava marchando pela mesma causa, mas agora sua obra seria inseparável da de seu aluno. Passaria a habitar inadvertidamente a casa alheia. Ora recôndito, ora revelado. 0 Mestre Subterrâneo. 


\section{REFERÊNCIAS BIBLIOGRÁFICAS}

BLOOM, Harold. La angustia de las influencias. Caracas: Monte Avila, 1973.

BIRMINGHAN, David. Kwame Nkrumah: The father of African Nation. Athens: Ohio University Press, 1998.

GARVEY, Marcus. A estrela preta. S.I: Eu\&Eu Realidade Rasta, 2013.

GERSHENHORN, Jerry. Melville J. Herskovits and the racial politics of knowledge. Lincoln/Nova York: University of Nebraska Press, 2004.

LÊNIN, V. I. Que fazer? Problemas cadentes do nosso movimento. In: LÊNIN, V. I. Obras Escolhidas. Vol. - I. São Paulo: Alfa-Ômega, 1986.

LINEBAUGH, Pete; REDIKER, Marcus. A hidra de muitas cabeças. Marinheiros, escravos, plebeus e a história oculta do Atlântico revolucionário. São Paulo: Companhia das Letras, 2008.

NKRUMAH, Kwame. Un líder y un Pueblo. Autobiografia. México-D.F: Fondo de Cultura Economica, 1962.

África debe unirse. Barcelona: Bellaterra, 2010.

Africa must unite! Nova York: Praeger, 1963.

. The spectre of Black Power. Londres: Panaf, 1968.

PAIVA, Felipe. Ecos africanos de outubro: Kwame Nkrumah e a sombra de Lênin. Lutas Sociais. São Paulo: PUC-SP, 2017, vol. 21, n. 37, p. 166 - 178. Disponível em: https:// revistas.pucsp.br/index.php/ls/article/view/33251/pdf.

SHERWOOD, Marika. Nkrumah: The years abroad (1935 1947). Acra: Freedom, 1996. 
STEINER, George. Gramáticas da criação. São Paulo: Globo, 2003.

TÓLSTOI, Liev. Obra completa - Vol. I. Rio de Janeiro: Nova Aguilar, 2010.

\section{AGRADECIMENTOS E INFORMAÇŌES}

\section{Felipe Paiva}

paiva.his@gmail.com

Doutorando em História - Bolsista Capes-Proex

Universidade Federal Fluminense

RECEBIDO EM: 1/6/2018 | APROVADO EM: 20/7/2018 